\title{
Analisis Efisiensi Usaha Sapi Perah di Kecamatan Selupu Rejang Kabupaten Rejang Lebong
}

Eficiency Analysis In Dairy Farming at Selepu Rejang District Rejang Lebong Regency.

\section{Sri Sugiarti}

Jurusan Sosial Ekonomi Pertanian Fakultas Pertanian Universitas Bengkulu Jalan Raya Kandang Limun, Bengkulu. Telp. (0736) 2170 pst.219.

\begin{abstract}
The objective of the research were to analyze the production and Profit in dairy farming and to identity the influencing factor on it twenty three farmers were chosen as respondents by sensus. The result showed that the production in dairy farming was positively correlated with number of dairy animals, education and age of dairy animal while grassland and labors was negatively influenced kept a production. That the profit in dairy farming was negatively correlative with grassland price, education and age of dairy animals while labors pay and number of dairy animals was positively influenced kept profit.
\end{abstract}

Keywords : Dairy farming, production, profit

\section{ABSTRAK}

Penelitian ini bertujuan untuk menganalisis produksi dan keuntungan di usaha ternak sapi perah dan factorfaktor yang mempengaruhinya. Jumlah responden sebanyak 23 peternak yang dipilih secara sensus. Hasil penelitian menunjukkan bahwa: jumlah ternak,pendidikan dan umur ternak berpengaruh positif terhadap produksi sedang pakan hijauan dan tenaga kerja berpengaruh negatif terhadap produksi. Harga pakan hijauan, pendidikan formal dan umur ternak berpengaruh negative terhadap keuntungan sedang upah tenaga kerja dan jumlah ternak berpengaruh positif terhadap keuntungan.

Kata Kunci : Usaha ternak sapi perah,produksi,keuntungan

\section{PENDAHULUAN}

Pengunaan pertanian merupakan salah satu pembangunan nasional. Tujuan pembangunan adalah terus menerus meningkatkan produksi pertanian baik untuk memenui kebutuhan konsumsi masyarakat yang terus meningkat, untuk memenuhi kebutuhan bahan baku industri maupun untuk terus menerus meningkatkan pendapatan devisa exspor hasil - hasil pertanian. Pendapatan pertanian sekaligus harus dapat memperluas kesempatan kerja, meningkatkan pendapatan, pemerataan kasempatan berusaha dan mendukung pembangunan daerah dengan memperhatikan sumber kelestarian sumber daya ( Departemen Pertanian 1984 )
Sub sektor Peternakan sebagian bagian yang tak terpisakan dari sektor pertanian mengemban tugas menyediaan bahan pangan asal ternak seperti daging, telur dan susu dalam jumlah dan mutu yang cukup serta harga yang terjangkau.

Pemenuhan kecukupan protein hewani secara nasional masih jauh dari target yang telah ditetapkan, Widya Karya Nasional Pangan dan Gizi sebesar 6 gram / kapita / hari eqwivalen dari konsumsi daging 10,1 kg / kapita / tahun, telur 3,5 kg / Kapita / tahun dan susu 6,4 kg / Kapita / tahun. Realisasi komsumsi protein hewani nasional pada tahun 1998 baru mencapai 3,4 gram / kapita / hari atau baru mencapai 65 persen dari yang ditargetkan. Dari pencapaian tersebut, konsumsi susu masyarakat pada tahun yang 
sama baru mencapai 4,6 kg / kapita / tahun sementara konsumsi susu masyarakat Bengkulu tahun 1999 1,5 kg / kapita / tahun atau baru mencapai 18 persen dari yang ditargetkan.

Rendahnya konsumsi susu bahan pangan asal ternak selain disebabkan oleh rendahnya daya beli masyarakat juga karena konsumsi susu belum cukup membudaya di masyarakat Indonesia, apalagi masyarakat Bengkulu. Pada umumnya susu konsumsi merupakan susu olahan yang harganya relatip mahal, sedangkan susu segar produksi sapi perah selama ini menjadi bahan baku industri, sebenarnya dapat dimanfaatkan untuk konsumsi langsung melalui pengolahan sederhana dengan harga yang lebih murah dan terjangkau oleh masyarakat

Kondisi persusuan nasional pada saat ini mengalami krisis produksi yang cukup serius, Pada tahun 1996 produksi sebesar 432,900 ton pada tahun 1999 menjadi 384.310 ton melihat produksi dalam negeri jika dibandingkan dengan inpor susu sebesar 4,6 juta ton berarti produksi nasional susu hanya dapat memenuhi sekitar $8-10$ persen dari kebutuhan, Dengan demikian jumlah susu sapi perah yang ada sekarang belum cukup untuk memenuhi konsumsi dalam negeri disebabkan iklim pemasaran susu kurang mengairakan petani peternak sapi perah. Kurangnya gairah ini salah satu sebabnya dikarenakan belum efisensinya usaha sapi perah yang menyebabkan biaya produksi tinggi dan akhirnya peternak akan menerima keuntungan yang kecil.

Populasi sapi perah di Indonesia pada tahun 1986 sebanyak 2032 ribu ekor. Sebanyak 194 ribu ekor sapi perah tersebut terkonsentrasi di pulau Jawa dan diluar Jawa, 9,2 ribu ekor sapi perah diantaranya terdapat di Bengkulu.

Dengan adanya kebijakasanaan pemerintah, maka secara tidak langsung akan merangsang peternak sapi perah untuk meningkatkan produksi susunya. Tetapi masalah yang dihadapi sekarang adalah bagaimana peternak sapi perah itu disamping dapat meningkatakan produksinya juga memperolah keuntungan yang memadai.

\section{MATERI DAN METODE}

\section{Metode Penelitian Lokasi dan Waktu Penelitian}

Lokasi penelitian dipilih dan ditentukan dengan sengaja (purposive), yaitu didesa air duku dan di desa APK Bandung Kecamatan Selepu Rejang Kabupaten Rejang Lebong, dengan pertimbangan bahwa lokasi tersebut merupakan daerah yang menerima bantuan sapi perah dari Dinas Perternakan Propensi Bengkulu. Penelitian ini dilakukan pada bulan Juli 2006.

\section{Sumber Data}

Data yang diambil dalam penelitian ini yaitu bersumber dari data primer dan data scunder. data primer adalah data yang diperoleh melalui observasi, survey dan wawancara dengan responden. data skunder yaitu yang diproleh dari literatur - literatur, informasi dari instansi - instansi yang terkait dengan topik penelitian

\section{Metode Penentuan Responden}

Populasi dalam penelitian ini adalah peternak sapi perah yang ada di daerah penelitian. pengambilan sample dilakukan dengan secara sensus., Berdasarkan informasi yang ada, bahwa didesa air Duku dan APK Bandung Kecamatan Selepu Rejang Kabupaten Rejang Lebong jumlah peternak yang memiliki sapi perah sampai tahun 2006 adalah 23 peternak dimana Desa air Duku mempunyai 11 orang peternak dan APK Bandung mempunyai 12 orang peternak.

Metode Analisa Data

Analisis fungsi produksi bertujuan untuk mengetahui hubungan faktor - faktor produksi secara teknis untuk menganalisis pengaruh faktor produksi terhadap produksi usaha sapi perah digunakan fungsi produksi Cabb Donglas yaitu sebagai berikut

$$
\begin{array}{lllllll}
\text { B1 } & \text { b2 } & \text { b3 } & \text { b4 } & \text { b5 } & \text { b6 } \\
\text { q } & \text { Ax } & x & x & x & x & x \\
1 & 2 & 3 & 4 & 5 & 6
\end{array}
$$

Karena fungsi produksi Cobb Donglas bersipat power fuction, maka ditrans formasikan dalam bentuk ln menjadi sebagai berikut : 
$\operatorname{Lnq}=\ln \mathrm{A}+\mathrm{b}_{1} \ln \mathrm{x}_{1}+\mathrm{b}_{2} \ln \mathrm{x}_{2}+\mathrm{b}_{3} \ln \mathrm{x}_{3}+\mathrm{b}_{4} \ln \mathrm{x}_{4}$ $+b_{5} \ln$

$$
\begin{aligned}
& \text { Disini } \\
& \text { A }=\text { Konstante } \\
& b_{i}=\quad i=(1,2,3,4,5,6, \quad) \text { elastisitas } \\
& \text { produksi dari faktor produksi yang } \\
& \text { dipakai } \\
& \mathrm{X}_{1}=\quad \text { Jumlah pakan hijauan }(\mathrm{kg} / \mathrm{th}) \\
& \mathrm{X}_{3}=\quad \text { Jumlah sapi perah (ekor) } \\
& \mathrm{X}_{2}=\quad \text { Jumlah tenaga kerja (jam / th) } \\
& \mathrm{X}_{4}=\quad \text { Pendidikan pormal (tahun) } \\
& X_{5}=\quad \text { Umur sapi perah } \\
& \mathrm{q}=\quad \text { Jumlah produksi } 1 / \text { th }
\end{aligned}
$$

Analisis fungsi keuntungan bertujuan untuk mengetahui hubungan faktor - faktor produksi secara ekonomis. Untuk menganalisis pengaruh faktor - faktor produksi terhadap keuntungan usaha sapi perah digunakan fungsi keuntungan Cobb Donglas yang telah dinormalkan sebagai berikut.

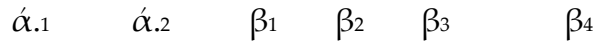

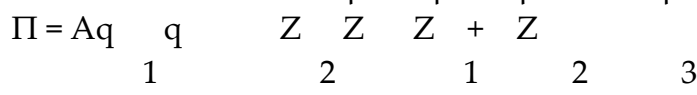

$$
\begin{aligned}
& 4
\end{aligned}
$$$$
\ln \Pi=\ln \mathrm{A}+\alpha_{1} \mathrm{Lnq}_{1}+\alpha_{2} \cdot \ln q_{2}+\beta_{1} \ln \mathrm{Z}_{1}+\beta_{1} \ln \mathrm{Z}_{2}
$$$$
+\beta_{3} \ln Z_{3}+\beta_{1} \ln Z_{4}
$$

Disini : $\Pi=$ Besarnya keuntungan yang telah dinormalkan dengan produksi

$\mathrm{q}_{1}=$ harga makanan hijauan yang telah

Dinormalkan dengan produksi

$\mathrm{q}_{2}=\quad$ Harga tenaga kerja manusia yang telah dinomalkan dengan produksi

$\mathrm{Z} 1=\quad$ Jumlah sapi perah (ekor)

$\mathrm{Z}_{2}=$ Pendidikan yang diproleh oleh peternak (th)

$\mathrm{Z}_{3}=\quad$ Pengalaman peternak (th)

$\mathrm{Z}_{4}=\quad$ Umur sapi perah $(\mathrm{th})$

$\alpha$.i,$\quad \beta_{i}=$ Koefisein regresi

$\mathrm{A}=\quad$ Konstante

Untuk mendapatkan estimasi fungsi produksi dan fungsi keuntungan di atas mengunakan cara metode kuadrat terkecil ( ordinary least square = OLS) menurut petunjuk Gujarati (1978)
Pengujian terhadap seluruh parameter yang dimaksudkan untuk mengetahui apakah variable independent secara keseluruhan berpengaruh nyata terhadap variable dependen

\section{Hipotisis yang diajukan adalah}

Ho : $\alpha_{\text {I }}=0$ Untuk semua i (semua koefisien regrasi dalam model nilainya tidak berbeda dengan nol)

Ha : $\alpha_{\text {I }} \neq 0$ (Untuk semua i salah satu koefisian regrasi dalam model nilainya berbeda dengan nol)

Pengujian hipotesa dengan mengunakan uji $\mathrm{F}$ tes $\mathrm{t}$

apabila $\mathrm{F}$ hit $\leq \mathrm{F}$ table (k,n- k-1), Ho diterima

apabila $\mathrm{F}$ hit $\geq \mathrm{F}$ table (k,n- k-1), Ho ditolak

Konsep dan Pengukuran variabel

1. Hasil produksi adalah jumlah hasil produksi dalam liter pada satu unit usaha sapi perah per tahun

2. Jumlah sapi perah adalah jumlah sapi perah yang perproduksi dalam ekor pada satu unit usaha sapi perah pada saat ini

3. Makanan hijaun adalah makanan hijaun yang diberikan dalam $\mathrm{kg}$ pada sapi perah yang berproduksi pada satu unit usaha sapi perah pertahun

4. Tenaga kerja manusia yang digunakan adalah jumlah tenaga kerja manusia yang digunakan dalam jam satu unit sapi perah per tahun

5. Pendidikan yang diperoleh peternak adalah lama pendidika dibangku sekolah oleh peternak sapi perah diukur dalam tahun

6. Pengalaman peternak adalah pengalaman peternak dalam mengusahakan usaha sapi perah diukur dalam tahun

7. Umur sapi perah adalah umur rata - rata sapi perah yang diproduksi pada satu unit usaha sapi perah diukur dalam tahun

8. Biaya riil adalah biaya yang nyata dikeluarkan oleh peternak dalam usaha peternak. Biaya ini meliputi biaya peralatan, inseminasi buatan dan lain - lain $\mathrm{Rp} / \mathrm{th}$ 
9. Biaya Variabel adalah biaya yang berubah disesuaikan dengan perubahan besarnya jumlah produksi. $\mathrm{Rp} / \mathrm{th}$

10. Penerimaan adalah penghasilan berupa uang hasil penjualan merupakan perkalian antara jumlah produksi susu yang dijual dengan harga jual susu tersebut. $\mathrm{Rp} / \mathrm{th}$

11. Keuntungan adalah selisih antara nilai penjualan hasil produksidengan biaya total yang dikeluarkan untuk melaksanakan proses usaha $\mathrm{Rp} /$ th

\section{HASIL DAN PEMBAHASAN}

\section{Keadaan Usaha Sapi Perah}

Umur para peternak sapi perah relatip berbeda - beda umur para peternak berkisar antara 30 sampai 61 tahun dengan rata -rata 45, 39 th, peternak sapi perah yang terbanyak adalah berumur $37-55$ tahun $(69,33$ $\%)$, dan paling sedikit adalah berumur kurang dari 31 tahun sebanyak 8, $71 \%$ Dilihat dari segi umur peternak sapi perah, maka cukup besar harapan untuk mengembangkan usaha peternakan sapi perah berada pada kelompok produktif, umumnya peternak berkeinginan untuk maju. Sesuai pendapat Mubyarto, (1977) yang menyatakan bahwa seseorang yang berusaha pada usia produktif akan memberikan hasil yang maksimal dibandingkan pada usia dibawah atau diatas usia produktif.

Pendidikan yang diperoleh para peternak sapi perah berkisar antara 6 sampai 12 tahun dengan rata - rata 7, 56 tahun. Peternak sapi perah yang terbanyak adalah tamat SD (60, 99\%) dan paling sedikit adalah berpendididkan tamatan SMU 12, 88\%. Ditinjau dari segi pendidikan yang diperoleh peternak maka cukup menunjang pengembangan usaha sapi perah. Hal ini sejalan dengan pendapat Mubyarto, (1977) bahwa memperbaiki cara berproduksi dan penjebaran cara - cara baru kepada petani melalui pendidikan dan penjuluhan, merupakan investasi penting yang hasilnya tidak dapat dianggap kecil.

Makanan hijauan yang diberikan pada peternak sapi perah di Kecamatan Selepu Rejang rata - rata sebesar 23, $29 \mathrm{~kg} /$ th / ekor. Pada umumnya makanan hijauan yang diberikan pada sapi perah terdiri dari rumput lapangan dan sisa hasil pertanian. Jumlah pemberian makanan pada usaha ternak sapi perah di Kecamatan Selepu Rejang ternyata lebih rendah dengan jumlah pemberian makanan hijauan pada usaha sapi perah di Bogor dan Sukabumi $38 \mathrm{~kg} /$ ekor / hari, demikian juga dengan komposisi hijauan yang diberikan (IPB, 1989), Untuk mendapatkan peroduksi yang lebih tinggi perlu diperhatikan kuantitas dan kwalitas dari pada makanan hijaun yang diberikan.

Makanan konsentrat yang diberikan pada usaha sapi perah di Kecamatan Selepu Rejang rata - rata sebesar 0,89 kg / ekor / hari. Secara umum makanan konsentrat yang diberikan pada sapi perah hanya dedak padi sedangkan pemberian makanan konsentrat pada usaha sapi perah di Bogor dan Sukabumi yaitu rata - rata 5,45 kg/ekor / hari dan komposisi makana konsentrat yang terbanyak adalah makanan dari pabrik diikuti oleh dedak padi (IPB, 1989). Pemberian konsentrat di Kecamatan Selepu Rejang dari segi kuantitas maupun kualitas adalah lebih rendah bila dibandingkan dengan yang diberikan di Bogor dan Sukabumi.

Pengalaman peternak sapi perah pada peternak di Kecamatan Selepu Rejang rata - rata sebanyak 3,5 tahun, Pengalaman peternak sapi perah bila dikaitkan dengan penguasaan teknologi peternak sapi perah dalam kondisi dan fasilitas serta pembinaan yang sama, maka peternak yang lebih berpengalaman dapat diharapkan menunjukan keterampilan yang lebih baik dalam penerapan teknologi berternak, Sehingga dapat menunjukan usaha yang lebih baik dibandingkan dengan peternak lain yang kurang berpengalaman, (IPB, 1989)

Produksi usaha sapi perah yang berupa air susu sangat menentukan keberhasilan dalam suatu usaha sapi perah, karena produksi yang berupa air susu merupakan produksi yang dapat dijual. Produksi usaha sapi perah di Kecamatan Selepu Rejang rata - rata sebanyak 8,47 L / ekor / hari. Bila dibandingkan dengan produksi rata - rata usaha peternakan di Kabupaten Malang sebesar 10,38 1/ekor / hari (Masduki 1989) maka produksi usaha sapi perah di Kecamatan 
Selepu Rejang relatip lebih rendah. Produksi perbedaan ini disebabkan karena jumlah makanan konsentrat yang diberikan di Kabupaten Malang lebih tinggi yaitu 6,77 kg / ekor / hari sedangkan di Kecamatan selepu Rejang 0, $89 \mathrm{~kg} /$ ekor / hari

Tenaga kerja manusia yang digunakan dalam usaha sapi perah perhari di Kecamatan Selepu Rejang rata - rata 2,93 jam, Pengunaan tenaga kerja digolongkan untuk memeras susu, mengantar susu kepenampungan, memandikan ternak, memberi makan ternak, membersihkan kandang dan lain - lain. Tenaga kerja yang digunakan berasal dari keluarga sendiri baik laki - laki maupun perempuan, tenaga kerja wanita biasanya digunakan untuk memberi makan ternak. Sesuai pendapat Fadholi Hermanto, (1989) bahwa tenaga kerja yang digunakan dalam kegiatan usaha tani sebagian besar dari tenaga kerja keluarga dan baru menggunakan tenaga kerja luar bila tenaga kerja keluarga tidak mencukupi.

\section{Analisis Fungsi Produksi Usaha Sapi Perah}

Menurut Soekartawi, (1986) Model yang digunakan dalam analisis ini adalah fungsi produksi Cobb Donglas dan sebelumnya ditransformasikan kedalam bentuk ln sehingga model regresinya menjadi model regresi linear berganda, maka menggunakan metode kwadrat terkecil biasa, Hasil estimasi fungsi produksi pada usaha ternak sapi perah disajikan pada table 1
Hasil perhitungan regresi memperlihatkan koefisien diterminasi $\left(R^{2}\right)$ sebesar 0,561 yang berarti 56,1 Variabel bebas (pakan hijaun, jumlah ternak, tenaga kerja, pendidikan dan umur ternak) secara bersama sama memberikan sumbangan sebesar 56,1\% terhadap produksi sapi ternak sedangkan sisahnya 43,90\% dijelaskan oleh faktor -faktor produksi yang tidak teridentifikasi dalam penelitian antara lain konsentrat, investasi, laktasi, suhu udara, kelembaban, curah hujan, keturunan dan lain - lain.

Tiga faktor produksi mempunyai koefisen regresi dengan tanda positip sedangkan dua faktor produksi bertanda negatip (pakan hijaun dan tenaga kerja), Hal ini berarti yang sesuai dengan tiori jumlah ternak, pendidikan, umur ternak, yang berarti setiap penambahan faktor produksi akan meningkatkan produksi, Pada faktor produksi pakan hijauan dan tenaga kerja akan menyebabkan produksi mengalami turun, Hal ini disebabkan pakan hijaun yang diberikan bukan rumput unggul, rumput yang ada dilapangan sedangkan tenaga kerja berasal dari tenaga keluarga yang tidak dibayar jadi sudah mengalami kejenuhan. Semua faktor produksi tidak berpengaruh nyata terhadap produksi pada tingkat $\alpha=5 \%$ hanya faktor produksi jumlah ternak berpengaruh pada produksi pada $\alpha .=30 \%$

Pada faktor produksi pakan hijauan tidak berpengaruh terhadap produksi usaha sapi perah, disebabkan peternak sapi perah di

Tabel 1 : Hasil estimasi fungsi produksi usaha sapi perah dikecamatan Selepu Rejang

\begin{tabular}{|c|c|c|c|c|}
\hline No & Variabel & Koefisien Regresi & Standar Error & Nilai T hitung \\
\hline 1 & Pakan hijaun & $-0,0266$ & 0,438 & $-0,061$ \\
\hline 2 & Jumlah Ternak & 0,798 & 0,638 & 1,252 \\
\hline 3 & Tenaga kerja & $-0,0027$ & 0,515 & $-0,012$ \\
\hline 4 & Pendidikan & 0,214 & 0,330 & 0,647 \\
\hline 5 & Umur ternak & 1,036 & 1,039 & 0,997 \\
\hline \multicolumn{5}{|c|}{ Konstate $=1,530$} \\
\hline \multicolumn{5}{|c|}{ F hitung $=4,349$} \\
\hline $\mathrm{R}^{2}$ & $=0,561$ & & & \\
\hline \multicolumn{5}{|c|}{ Sumber : Data primer diolah 2006} \\
\hline \multicolumn{5}{|c|}{$F(0,05 ; 17 ; 5)=2,18$} \\
\hline \multicolumn{5}{|c|}{$\mathrm{T}(0,05 ; 17)=2,11$} \\
\hline $\mathrm{T}(0,30$ & 17) $=1,069$ & & & \\
\hline
\end{tabular}

Jurnal Sain Peternakan Indonesia Vol. 3, No 2. Juli - Desember 2008 
Kecamatan Selepu Rejang didalam memberikan pakan hijauan masih rendah dibandingan usaha sapi perah didaerah maju seperti Bogor, (IPB, 1989)

Faktor produksi tenaga kerja tidak berpengaruh nyata usaha sapi perah terhadap produksi disebabkan tidak efisiennya tenaga kerja yang digunakan

Faktor produksi pendidikan yang diproleh peternak tidak berpengaruh nyata terhadap produksi usaha sapi perah. Pendidikan yang diperoleh peternak walaupun lebih tinggi belum tentu meningkatkan hasil produksi dibandingkan dengan peternak berpendidikan rendah. Peternak yang berpengalaman lebih lama cenderung menunjukan keterampilan yang lebih baik dalam penerapan teknologi beternak sehingga akan meningkatkan produksi. (Mubyarto, 1977)

Pada faktor produksi umur sapi perah tidak berpengaruh terhadap produksi usaha sapi perah disebabkan peternak sapi perah di Kecamatan Selepu Rejang didalam memelihara ternak sapi perah masalah umur sapi perah tidak masalah pokok selama sapi perah yang dipelihara masih berproduksi tinggi walaupun umurnya sudah tua peternak masih memeliharanya. Menurut Sulistiowati, (2006) Volume produksi susu sapi perah yang maksimal dicapai pada umur 5 sampai 10 tahun, setelah umur tersebut produksi susu sudah berkurang dan sebelum umur tersebut produksi susu sapi perah belum optimal.

\section{Analisis Fungsi Keuntungan Usaha Sapi Perah}

Menurut Soekartawi, (1986) . Model fungsi keuntungan yang digunakan adalah fungsi keuntungan Cobb - Dongglas. Hasil estimasi fungsi pada usaha ternak sapi perah disajikan pada table 2

Dari hasil estimasi dengan mengunakan model Cobb donglas pada table 2 terlihat bahwa secara bersama - sama seluruh variable berpengaruh nyata terhadap keuntungan dengan nilai $F$ hitung 3,002 yang lebih besar dari $\mathrm{F}$ table 2,70 pada tingkat kepercayaan $95 \%$. Koepisien diterminasi ( $\mathrm{R}^{2}$ ) menunjukan nilai sebesar 0,469 berarti 46,9\% Variabel bebas harga pakan hijauan, upah tenaga kerja, jumlah ternak, pendidikan formal dan umur ternak secara bersama - sama memberikan sumbangan sebesar $46,9 \%$ terhadap keuntungan usaha sapi perah sedangkan 53,1 \% lainnya dipengaruhi faktor lain yang belum diindentifikasi kedalam model misalnya investasi, bulan laktasi,suhu lingkungan, kelembaban, curah hujan dan lain - lain.

Koefisien regresi bertanda negatif ini sesuai dengan apa yang diharapkan dalam teori ada tiga yang berarti setiap peningkatan

Tabel 2 : Hasil estimasi fungsi keuntungan usaha sapi perah di kecamatan Selepu Rejang

\begin{tabular}{lccc}
\hline \multicolumn{1}{c}{ Variabel } & Koefisien Regresi & Standar Error & Nilai Thitung \\
\hline Harga pakan & & & \\
Hijaun & $-0,079$ & 0,400 & $-0,196$ \\
Upah tenaga kerja & 0,291 & 0,359 & 0,811 \\
Jumlah ternak & 0,811 & 0,273 & 2,962 \\
Pendidikan pormal & $-0,070$ & 0,455 & $-0,158$ \\
Umur ternak & $-1,525$ & 1,029 & $-1,483$ \\
\hline Konstante =2,131 & & & \\
F hiting $=3,002 \quad=0,469$ & & & \\
$\mathrm{R}^{2}$ & & & \\
\hline
\end{tabular}

Sumber data primer diolah, 2006

F Tabel $(0,005: 17: 5)=2,81$

T Tabel $(0,05: 17)=2,11$

T Tabel $(0,20: 17) \quad=1,337$ 
harga faktor produksi variabel akan mengakibatkan tingkat keuntungan usaha sapi perah berkurang. Sebaliknya ada dua yang bertanda positip yang berati sitiap peningkatan harga factor produksi variable akan mengakibatkan tingkat keuntungan usaha sapi perah bertambah.

Harga makanan hijauan yang dinormalkan tidak berpengaruh terhadap keuntungan ini disebabkan karena variasi harga makanan hijauan sedikit sekali antara tempat satu dengan tempat lainnya. Makanan hijaun didapat dari tenaga kerja merumput yang di upah jangka waktu tertentu, variasi upah tenaga kerja untuk merumput tidak begitu banyak, sehingga harga perkesatuan makanan hijauan yang diberikan pada ternak sapi perah tidak begitu variasi. Sesuai dengan penelitian yang dilakukan Masduki

Upah tenaga kerja tidak berpengaruh nyata terhadap keuntungan usaha sapi perah, Dikarenakan petani tidak mempersoalkan dengan kenaikan upah tenaga kerja dan meningkatnya upah tersebut dipandang sangat wajar sebagai penyesuaiyan terhadap kenaikan harga - harga kebutuhan hidup sekarang. Meningkatnya upah tenaga kerja menyebabkan petani mengurangi jumlah tenaga kerja sehinga biaya yang dikeluarkan petani menurun maka ada kecenderungan menaikan keuntungan. Sesuai hasil penelitian R Dewi Lestari, (2002)

Faktor produksi jumlah ternak berpengaruh terhadap keuntungan ini disebabkan dengan meningkatnya jumlah ternak maka produksi susu meningkat sehingga keuntungan yang diperoleh akan meningkat.

Faktor produksi tetap pendidikan tidak berpengaruh terhadap keuntungan. Berarti pendidikan yang diperoleh peternak tidak selalu meningkatkan keuntungan dimana keuntungan adalah merupakan nilai produksi dikurangi biaya produksi. Tingkat pendidikan lebih tinggi cendrung bisa mengetahui biaya biaya mana yang seharusnya tidak perlu dikeluarkan atau perlu dikeluarkan dalam proses produksi. Sesuai pendapat Mubyarto, (1977) melalui pendidikan dan penyuluhan merupakan investasi penting yang hasilnya tidak dapat dianggap kecil.
Faktor produksi tetap umur sapi perah berpengaruh terhadap keuntungan ini disebabkan semakin tinggi umur sapi perah semakin rendah produksi susu sapi perah, sehinga semakin tinggi umur ternak sapi perah samakin rendah keuntungan. Sesuai pendapat Sulistiowati, (2006) bahwa volome produksi susu sapi perah yang maksimal dicapai umur 5 sampai 10 tahun

\section{SIMPULAN}

Dari hasil penelitian dan pembahasan sebelumnya dapat disimpulkan sebagai berikut :

Faktor - faktor produksi makanan hijauan yang diberikan tenaga kerja yang digunakan, pendidikan dan umur ternak tidak berpengaruh terhadap produksi. Sedangkan jumlah ternak yang diusahakan berpengaruh terhadap pruduksi usaha sapi perah di Kecamatan Selepu Rejang.

Faktor produksi jumlah ternak dan umur ternak berpengaruh terhadap keuntungan usaha sapi perah di Kecamatan Selepu Rejang sedangkan faktor produksi harga pakan hijauan yang telah dinormalkan, harga tenaga kerja yang dinormalkan, pendidikan yang diperoleh tidak berpengaruh terhadap tingkat keuntungan.

\section{DAFTAR PUSTAKA}

Boediono, 1984. Ekonomi Mikro, Sri Sinopsis Pengantar Ilmu Ekonomi No 1 Penerbit Fakultas Ekonomi UGM Yogyokarta.

Hernanto F, 1989. Ilmu usaha tani Departemen Ilmu - Ilmu Sosial Ekonomi Fakultas Pertanian IPB Bogor

IPB, 1989. Pengkajian Biaya Produksi Usaha Peternakan sapi perah di wilaya Kerja GKSI Bogor Sukabumi. Kerjasama GKSI Fakultas Peternakan IPB. Bogor

Masduki, 1989. Analisis Efisensi usaha sapi perah didaerah Pujon Kabupaten Malang, Fakultas Pascasarjana UGM Yogyakarta

Mimi Suryani, 2007. Analisis Faktor - Faktor Produksi dan pendapatan Peternak 
sapi perah di desa air duku dan APK Bandung Kecamatan Selepu Rejang Kabupaten Recang Lebong.

Mosher, A.T. 1985. Getting Agrikultural Moving, Disadur oleh Krisnandi dan Brian Semed. Mengerakan dan membagun Pertanian. Jasaguna Jakarta

Mubyarto, 1977. Pengantar Ekonomi Pertanian. LP3ES Jakarta

Sulistiowati, 2006. Suplemen Tabut Blok pada sapi perah praktasi untuk Memodifikasi Asam premak, Jurnal Penelitian Fakultas Pertanian Unib
R Dwi Lestari, 2006. Fungsi keuntungan determinan dan lembaga pemasaran pada usaha tani padi sawah di desa penanjung panjang Kecamatan Tebat karai Kabupaten Kapahiang.

Siregar, M.E. 1985. Upaya peningkatn keuntungan peternakan dalam memelihara sapi perah di daerah pengalengan Jabar, Ilmu dan Peternakan Pusat Penelitian dan pengembangan peternakan peptan.

Soekartawi, 1986. Analisis Fungsi Cobb donglas tiori dan Aplikasinya. Fakultas Pertanian Unibraw 